\title{
TURKEY AND IRAN TOWARDS THE FIRST WORLD WAR*
}

\author{
TÜRKKAYA ATAÖV
}

\section{Introduction:}

This paper intends to focus on some highlights of the role that two neighbouring countries, Iran and Turkey, played during the First World War. While both had separate identities and decision-making processes, although not entirely independent as one might wish, the events in Iran were inseparably connected with the events in the Asiatic part of the former Ottoman Empire and with the great power policies towards the Turks during that war.

The beginning of the twentieth century is an interesting and a complex period in the histories of both Iran and Turkey. It was a period of bloodless revolutions, in 1905 in Iran, and in 1908 in Turkey. It was an epoch in which Iran was divided up initially overtly (1907) and then secretly (1915). The Ottoman Empire, similarly, shrank, losing almost all of its European possessions. Moreover, great power rivalry provided the impulse for a general conflagration to partition the world.

Both Iran and Turkey being targets of stronger European powers, the interests of the former were theoretically parallel. Although the years 19141918 may be divided into various phases, it may be asserted that the attitude of Iran, hard pressed under Russian and British occupation as well as German propaganda and cocrcion, was, on the whole, friendly to the Turks. The secret agrecments, disclosed by the Bolshevik government in the last year of the

\footnotetext{
* Paper submitted to the International Round Table on "La Perse et la Grande Guerre," Tehran, 2-3 March 1997.
} 
war, demonstrated how the great powers could infringe upon the sovereignty of both states.

Besides, for neither of the two did the war end in 1918. Various kinds of military operations continued on Iranian territory up until 1921, and Turkey found itself in the midst of a national liberation struggle that lasted even later than that.

\section{History, Geopolitics and Culture:}

In addition to many parallel lines in the circumstances of these two neighbours, there was a lot of history involved in both cases, enmeshed with remarkable culture set in a particular geographical environment, some aspects of which placed them in competing positions. Iran's relations with anyone of its neighbours are determined by history and geopolitics, even though there may be changinges as well as continuing bearings on these determinants. ${ }^{1}$ The latter influence and even stir the behaviour of the nation and the state's foreign policy.

History is much more than a narrative. It frequently involves "chosen traumas" and "chosen glories", many of which may become part of the nation's identity, events of hurt or dignity passed from one generation to another. ${ }^{2}$ At times, people even have a psychological investment in the continuation of a given conflict. ${ }^{3}$ Indeed, "few countries can rival Iran in the length and the variety of her history." 4 It is "one of the few ancient civilizations that, owing to its genuineness, has survived the onslaught of time and circumstances." ${ }^{5}$ Iran distinguishes itself as representing one of the most ancient cultures of the world, comparable in Asia to those of China and India. Its long history provides it with an appreciation of continuous nationhood and statehood in a region where many other nationalities were

${ }^{1}$ A contemporary American author examines the character of Iran's relationships with each of its neighbours in order to identify issues, patterns and constants within these relationships. Graham E. Fuller, The "Center of the Universe": The Geopolitics of Iran, Boulder, San Francisco, Oxford, Westview Press, 1991.

${ }^{2}$ V.D. Volkan and M. Harris, Sharing the Tent, Charlotsville, Center for the Study of Mind and Human Interaction, 1998.

${ }^{3}$ Vamik D. Volkan, The Need to Have Enemies and Allies: From Clinical Practice to International Relationships, Northvale, New Jersey and London, Jason Aronson Inc., 1994.

${ }^{4}$ John A. Boyle, ed., Persia: History and Heritage, London, Henry Melland, 1978, p. 17.

${ }^{5}$ A. H. Nayer-Nouri, Iran's Contributions to World Civilization, Tehran, Ministry of Culture and Arts Press, 1969, p. 5. 
mere protectorates during the First World War, and some are still very young nation-states.

Iran's pride in a superior culture, however, is balanced by occasional sense of insecurity caused by foreign domination in the past. Its experience with the British and the Russian empires (and later with American preponderance) forced Iran to be sensitive towards great power dominance, a feeling conveniently combined with the psychology of persecuted Shi'ism.

\section{Iran and Turan:}

Iran and Turan, the lands of the Farsi and Turkic-speaking masses, existed side by side in the Middle East and Central Asia. Their cultures intermingled as much as parts of their territories. There were times when the Seljuk Turkish sultans, who utilized Farsi in their courts, ruled from a Persian capital, Isfahan.

Persia became Muslim as a result of Arab conquests. ${ }^{6}$ While Persian influence was felt after the transfer of the capital of the Islamic Empire from Damascus to Baghdad (A.D. 750), the Persian language, swarmed with Arabic words, came to be written in the Arabic script. Changing climatic, political and military conditions in the Altaic homeland in Central Asia sent, on the other hand, in several directions, successive masses of nomads who called themselves Oğuz (Oghuz) and known by others as Turkomans or Turks. These tribes entered Persian territory as well and ruled over parts of it for a few centuries.

The Great Seljuks, a group of Oghuz warriors came to be, however, champions of orthodoxy in the Islamic world. It was during their rule that the basic politico-economic form in Persia was established. Based on the allotment of picces of land to petty territorial rulers, who were expected to provide the sultan with military contingents, the system lasted until the twenticth century with some modifications.

While the Great Seljuk Empire, then centered in Isfahan, reached its peak, much of Anatolia was transformed into a Turkish dominion. The Scljuk rule was even then undermined by the activities of various Shi'a groups. Even after the disintegration of the Seljuk state, the interaction between the Persians and the Turkic peoples continued. For instance, the Ilkhan dynasty, founded by Jenghiz. Khan's grandson Hulagu, ruled Persia as vassal of the Great Khan in Karakurum. After a short interval of a Persian

${ }^{6}$ The decisive battles with the invading Muslim Arabs, fought at Qadisiyya (A.D. 637) and Nihavand (A.D. 641), have become "chosen glories" for some Arabs, for instance Saddam Hussein of Iraq who chose to describe his war with Iran (1980-88) as "Saddam's Qadisiyya". 
dynasty, Persia again fell under the domination of another Turkic conqueror, Timur. With the death of his son, the western part of Iran fell first to the Turkomans of the Black Sheep and then to the Turkomans of the White Sheep, and Transoxania was overwhelmed by the Uzbck Turks.

The championship of Shi'ism as the official religion of Persia since the very beginning of the sixtecnth century, however, set that country at odds with the rest of the Muslim world, including the Sunni-dominated Ottoman Empire, which in a way succeeded the Seljuk state. While Shah Isma'il (1502-24) laid the foundations of the Shi'ite Persian Safavid empire, he also fostered a sense of sui generis existence and righteousness, no matter to what degree it may be impregnated with a desire for regional influence.

It was the Ottoman Sultan Selim I who felt the need to turn to the Safavids as Shah Isma'il pursued a policy of supporting his partisans in Anatolia. The decisive battle, fought at Chaldiran (1514), brought victory to the Ottomans and loss of prestige to Isma'il. It was difficult afterwards for the Safavids to carry on propaganda against Muslim orthodoxy in Ottomancontrolled lands.

Although the Ottomans took Tabriz (1725) and the reign of the Turkic Qajar dynasty lasted until 1925, the Persians and the Turks soon recognized the legitimacy of each state's faith within its frontiers, just as the monarchs of Europe learned to respect in mid-seventecnth century each other's choice of religion.

\section{The Persian Gulf - a "British Lake":}

The seventeenth and the eighteenth centuries witnessed efforts of the British colonialists who tried to make the Persian Gulf a "British lake". 7 Playing up the conflict between Persians and Turks over Basra and between the sultan's court in Istanbul and the Turkish governors in Baghdad, the British wrung from the local Turkish authorities permission to open trade stations. On the pretext of defending its trade interests, agents of the British East India Company intervened in the struggle between Nadir Shah, on the one hand, and the Turkish rulers in the three provinces of what is called Iraq today, on the other. This was the beginning of active British interference in Iranian-Turkish relations. London's cunning plan was to send (1739) John Elton, an agent of Britain's Moscow trading company, to offer Nadir Shah his services to establish a large Iranian navy - not in the Persian Gulf, but on the southern shore of the Caspian.

\footnotetext{
${ }^{7}$ Grigori Livovich Bonderevski, Gegemonisti i Imperialistl b persidskom Zalibe (Hegemonists and Imperialists in the Persian Gulf), Moscow, Novosti, 1981, pp. 47f.
} 
The British, not only actively interfered in the conflict between Iran and the Ottoman Empire, tried to shift Iranian interests from the Persian Gulf to the Caspian, and hampered the creation of an Iranian navy in the Persian Gulf, but also worsened relations between Iran and Russia, drew the peoples of the region into their wars with the Netherlands and France, exploited differences between the Shi'ites and the Sunnis and restored their privileges in Iran, even getting illegal payments from customs duties levied in Bender Abbas. The first treaty (1763) in Anglo-Iranian relations gave exclusive privileges to the British East India Company. The British resorted to every means, pulling appropriate strings in various capitals, assassinating some rulers, bringing other claimants to power, barbarously shelling coasts and forcing sheikhs, sultans and shahs to join the crippling treatics, which reduced the latter to protectorates and semi-colonies.

While British influence grew in India and the Gulf, Tsarist Russia acquired territory from Persia through the Treaties of Gulistan (1813) and Turkmenchai (1828). Britain and Russia eventually joined hands in a convention (1907) dividing the country into three areas, the two European countries undertaking not to scek concessions in their respective areas of influence.

Although the term "Persian Gulf" was the time-honoured name for that sea, ${ }^{8}$ one could not consider Iran as a true Gulf power until the reign of the last Pahlavi shah. Few countries with such cultural greatness suffered foreign control that lasted for such a long time. Even the National Assembly, after the Constitution of 1906, was suppressed (1908) by the shah with the help of an effective Cossack Brigade under Russian officers. ${ }^{9}$

\section{Massacres and Forced Migration:}

Although not yet divided and occupied, the difficulties that the Turks were facing reached such a pitch that a prominent Turkish historian describes the latter part of the $1800 \mathrm{~s}$ as "the longest century of the Ottoman Empire". ${ }^{10}$ It was a long tedious century involving recurring aggressions, brutal invasions, swift sccessions, humiliating defeats, bloody massacres and forced migrations. The transition of the Ottoman society from empire to nation or from ethnic diversity to Turkish nationalism is often commented

\footnotetext{
${ }^{8}$ Türkkaya Ataöv, "The Gulf and Its Name," Turkish Daily News, 22 February 1991.

${ }^{9}$ E.G. Browne, The Persian Revolution of 1905-1909, London, Cambridge University Press, 1910.

10 tlber Ortaylı, Imparatorluğun En Uzun Yüzyılı, Istanbul, Hil Yayınları, 1983.
} 
upon as a conspiratorial scheme designed to intimidate some neighbours and realize an all-embracing Turkic empire in the process.

The emergence of Turkish nationalism on the eve of the First World War may be better assessed as a reaction to a century-old anti-Turkish antagonism wrapped up in revolts, slaughter, ethnic cleansing and expulsion. Likewise, it should also be corrected that the ideas of "Turkism" did not originate in the "home country", that is, in the Ottoman Empire (or in the Republic of Turkey), but in the diaspora. It was a response opposing the irredentism of some neighbours. It had initially started among the Crimean Tatars, a Turkic people, to guard themselves against Russification and Christianization.

In the beginning of the nineteenth century there existed a huge and unbroken Muslim land, all the way from Bosnia, throughout the Balkans, up to Central Asia and even beyond, via the Crimea and its vast hinterland as well as Caucasia, inhabited mostly by Muslims. Most of that territory was, then, within the Ottoman Empire. The Muslims constituted the overwhelming majority or plurality in some regions or were sizeable minorities in some others. The Balkan Turks were either killed or forced to migrate by the combined efforts of some non-Turkish peoples of that subcontinent. The Russians inflicted the same fate on a varicty of Muslim groups in northern Caucasia, Russian Armenia and the Crimea. ${ }^{11}$

Millions of Muslims, mostly Turks, were killed, and many more millions were forced to migrate to safer areas in the Ottoman Empire. The unity of the different Christian peoples was attained through the murder and the expulsion of Muslims. Such actions, which began with the Greck Revolt in 1821 , were carried out mainly under the epitaph of "national liberation", forming frequently the basis and the cause for the enlargement of the new

\footnotetext{
${ }^{11}$ Much of the history of the Balkans, Anatolia and Caucasia cannot be understood without consideration of the Muslim dead and the Muslim refugees. If the contemporary map of the Balkans and southern Caucasus displays some countries with fairly homogenous populations, it is because their ethnic or religious unity was realized through the massacre and the expulsion of their Muslim population. Some Christian states, large or small, often portrayed as representatives of European culture, brought death to Turks and other Muslims. Despite this historical fact, textbooks and histories do not mention such occurrences. One non-Turkish exception: Justin McCarthy, Death and Exile: The Ethnic Cleansing of Ottoman Muslims, 1821-1922, Princeton, New Jersey, the Darwin Press, Inc., 1995. A Turkish diplomat, himself a refugec from Bulgaria, published a series of volumes which throw some light on the Turkish refugees from the Balkans. His first publication: Bilâl Şimşir, Rumeli'den Türk Göçleri, Ankara, Ayyıldız Matbaası, 1965.
} 
Christian states. Western books and articles frequently refer to Muslim misdeeds, actual or imaginary and to the massacre of Armenians, Bulgarians and Greeks, portraying especially the Turks as victimizers, but never, or very scldom, as victims.

The Ottoman administration, on the other hand, cognizant of the military, economic and technological differences between itself and Western Europe, was trying, during most part of the nineteenth century, to narrow that disparity and limit as much as possible the chances of its people to be slaughtered by its Christian insurrectionists, and offer land and work for those who survived.

The Greek insurrection saw the first event during which a great many Muslim Turks were either killed or forced to migrate from the lands that the latter had lived about five centuries. Turkish deaths were not the inevitable consequence of a military confrontation. Christian groups attacked Muslim quarters, villages and towns and murdered the civilian inhabitants. Just as the Portuguese had set a bad example of exceptional brutality, in and around the Indian Ocean in the sixteenth century, by cutting the ears and noses of the captured Muslim pilgrims destined for Mecca, the Greeks in the Balkans, some three centuries later, had shown the way to some other Balkan Christian groups such as the Bulgarians and Serbs what they could do to Muslim inhabitants. Apart from the Turks, the Abkhaz, Albanians, Azeris, Bosnians, Chechens, Circassians, Daghestanis, Pomaks, Tatars, and also the Jews, were frequently among the victims. Even Turks, given a promise of safe passage, were killed after abandoning their homes and lands. Their rescue by Ottoman forces were exceptions. If the Ottoman response, no matter how late and limited, was also crucl, it was the latter that captured the headlines in the European press.

Tsarist Russia as well constantly expanded at the expense of the Muslim Turkic peoples. Ivan the Terrible (1533-84) brought the Tatar Khanates of Kazan and Astrakhan to an end. Catherine the Great (1729-96) declared the Russian annexation of the Crimea. The Tatar emigration from ancestral lands had started even earlier than that. (Stalin displaced in 1944 the rest who had remained.) Russian expansion in the Caucasus was similarly accompanied by Muslim expulsions or escapes. The policy there as well was to change the demographic realities giving Christians preponderance over the Muslims. Consequently, many surviving Muslims had no choice but to migrate to the safer comers of Anatolia.

Whether Turks, Tatars or Azeris, the Muslim peoples secmed to the Christians as obstacles in the way to purely homogenous independent Christian kingdoms or republics. Almost all Christian peoples of the multinational or multi-religious Ottoman state tried to physically exterminate or expel the Muslim who "stood in their way." 
Hence, aggression, occupation, massacre, ethnic clcansing and expulsion in contemporary Bosnia-Herzegovina constitute only the last link in a long chain of similar events with roots in the last century. What befell on the present-day Bosnian Muslims once again was a bloody process that actually started back in 1821 with the Greek Revolt. It continues in the sense of discrimination towards the Turkish minorities in Western Thrace (Greece) and in Bulgaria (especially in 1984-89). The Serbs, who often referred to Bosnian Muslims as "Turks", considered them a reminder or an extension of the Ottomans. ${ }^{12}$

\section{Turkism:}

Under the circumstances, the rise of nationalism in Turkish intellectual and administrative circles on the eve of the First World War was reflected in foreign historiography mainly as an indication of racism, irredentism and expansionism. Even today, the demise of the former Soviet Union and the independence of several Turkic republics as well as present-day Turkey's close relations with them all create in some foreign circles concern that this new development may whip up "Turkism".

Turkish perception is rather different. I reminded above that the ideas related to Turkism did not originate in the home country, but in the diaspora, differing in this respect from Pan-Hellenism, Pan-Slavism, Pan-Germanism or Pan-Italianism. It is also important to note that their inception unfolded on the cultural plane with emphasis on unity or similarity in language, literature, folklore and history. Its propagators felt themselves justified because they had more than their share of competitors or opponents in the forms of sobornost as described by the Slavophiles, the Megali Idea of the Grecks, the racism of some Bulgarians and similar irredentism of some other neighbours. While some other nations had only one opponent image, the Turks had several adversaries. (It may also be recorded that no matter where and how "Turkism" might have originated or developed, the governments of the Republic of Turkey have never committed themselves to Pan-Turkism and never went beyond acknowledging the fact that there is an obvious cultural affinity among all Turkic-spcaking peoples. Atatürk's nationalism was Turkey-centered.)

The ideology of Turkism originated outside the Ottoman frontiers, mainly in response to the "pan-ideologies" of other nations. The policy of Russification, often accompanied with Christianization, provoked the Turkic groups in the Tsarist empire to be increasingly aware of common ties with

${ }^{12}$ Vamik D. Volkan, "Bosnia-Herzegovina: Ancient Fuel of a Modern Inferno," Mind and Human Interaction, 7/3 (August 1996), pp. 110-127. 
each other and most particularly with the Turks in the Ottoman Empire. The response of these groups, extending over vast territories, was expressed in Islamic as well as in nationalist parameters.

The Tatars had been under Russian domination longer than the other Turkic groups. They asserted their nationalist characteristics especially after the emergence of an active Tatar middle class which rivalled its counterparts in business. Their spokesman was Isma'il Gaspiralı (1851-1914), the mayor of the Crimean Tatar town of Bahçesaray, who founded a Turkish newspaper called Tercüman (Interpreter) and devised a new school program introducing Turkish as the means of instruction. His ideas were repeated by other Turkish papers in Azerbaijan and Central Asia. There were reportedly about 250 such papers printed in Tsarist Russia between 1905 and 1917. Whilc Turkic congresses met in some leading Russian cities such as Nidzhni-Novgorod and St. Petersburg, emerging Turkic writers such as Ali Hüzeyinzade (18641941) and Yusuf Akçura (1870-1935) lauded Turkism as a means of achieving the "unity of the Turks."

Similar ideas were carried to Istanbul only when leading Tatar intellectuals like Hüzeyinzade and Akçura and (the Azeri) Ahmet Ağaoğlu (1860-1939) left Russia and settled in the Ottoman capital. A Turkish Society (Türk Derneği) formed (1909) to coordinate the activities of various groups, was changed (1911) into the Turkish Homeland Society (Türk Yurdu Cemiyeti), under the leadership of Akçura and Ağaoğlu, who tried to promote the common interests of the Turks wherecver they might live.

The writings of Ziya Gökalp (1876-1924), a great Ottoman sociologist and thinker, provided the ideological basis of an intellectual movement for a transition from empire to nation and from religious to secular mentality. His conceptions offered the means to build a new nation, instead of suffering the immense losses. Putting forward ideas on nationalism, expressed in essays, didactic poetry and children's stories, he pushed aside Islamism and Ottomanism, which were still the dominating trends of thought at that time. Rejecting racism, he suggested the acceptance of Western models without turning one's back to national culture (hars). He criticized the Tanzimat (Re-ordering, 1839-76) for imposing the outward manifestations of Western civilization without cultivating the cultural base of the nation. Islam, as a source of cthics, could cocxist side by side with a modern national culture, but the religious endowments, which diverted much of the wealth of the nation, had to be taken away from the control of inefficient guardians. Prayers had to be carricd out in Turkish, and the Qoran taught in the national language. ${ }^{13}$

${ }^{13}$ Kâzım Nami Duru, Ziya Gökalp, Istanbul, 1948; Niyazi Berkes, ed., Turkish Nationalism and Western Civilization: Selected 
The Ottoman Empire now being shared principally with the Muslim Arabs, it was not surprising that Islamicists also grew. Mehmet Âkif (18701936), the poet of Albanian origin who later composed the Turkish National Anthem, and other conservatives disapproved of "union" with the Turks of the world to the detriment of "Islamic union."

Abdullah Cevdet (1869-1932), who initially expressed his ideas in a journal (Íçtihad, Struggle) printed in Geneva, advised the total replacement of the old with Western civilization. Gökalp and Cevdet provided much of the ideological background of Kemalist reforms during the Republican era. But on the eve of the First World War, in accordance with Gökalp's teachings, schools and religious courts were secularized, and the sheikh-ul Islam (chief jurisconsult) retained only religious consultative functions. Women, admitted to higher schools, began to remove the veil in public. It was under these circumstances that a new socicty called the Turkish Hearth (Türk $O$ cağ $l$ ) aimed to combat the ideas of Islamism and Ottomanism. While the branches of this society became the centers for education in Turkish cultural heritage, some encounters with the Turks in the diaspora were realized. The Arab national movement, in part instigated by the enemies of the Turks during the war, facilitated the search for this new Turkish identity. Consequently, the Society (Committee) of Union and Progress (CUP, Ittihat ve Terakki Cemiyeti), formerly a supporter of Ottomanism and now providing the ruling elite of an empire approaching a world war, also turned toward nationalism.

\section{Iran and Turkey in 1914:}

In 1914, Iran was an independent country but with a feudal structure, the state headed by the last representative of a disreputed Qajar dynasty. While British capital controlled the financial life of the country, Russia dominated over the only efficient military force, the Shah's Cossack Brigade. These two European states had divided Iran into northern and southern spheres of influence, the central region left to its actual owners merely as a "buffer" zone. The Germans, now moving closer to neighbouring Turkey, successfully extended their trade with Iran, as part of a general drive to take Britain and Russia out of the country. Only the rivalries between these great powers gave Iran some freedom to maneuver.

The Turks, on the other hand, had fought three wars in two continents within the very brief period of 1911 and 1913. The Ottoman Empire faced Italian attack (1911) at Tripolitania just three years before the outbreak of the

Essays of Ziya Gökalp, New York, 1959; Ziyaeddin Fahri, Ziya Gökalp, sa vie et sa sociologie, Paris, 1935. 
First World War. Encountering effective resistance, the Italians tried to pressure the Turks by occupying the Dodecanese Islands off the south Aegean coast.

The Albanian Revolt (1912) convinced the Turks that it was inconceivable to harmonize various national interests and attain a unified empire, and consequently, while the conservatives pinned hopes on Islam, the secularists more and more moved towards Turkish nationalism.

Even more dramatically, the Ottomans, with far fewer men under arms than the combined Balkan armies, had to fight their European neighbours in the First Balkan War (1912). Montenegro moved into Novipazar and Albania; Serbia took Kosovo and much of Macedonia; Greece annexed Crete and pushed toward Macedonia, reaching Salonica; Bulgaria laid siege around the centuries-old Turkish city of Edirne. The Ottomans had lost nearly all their European territories and tried to erect the last defence point at Çatalca just before Istanbul. New waves of refugees once again poured into the capital and the secure areas of Anatolia. Even the deposed (1908) Sultan Abdulhamid II was brought back to Istanbul just before the Greeks overwhelmed Salonica. The Treaty of London (1918) established the Midye-Enez line as the new Ottoman boundary.

The Turks could take back eastern Thrace and Edirne because the territorial disputes among the Balkan victors changed the military balance in favour of the Turks, who nevertheless lost 83 percent of their land. Enver Paşa (1881-1922), who had led the famous "raid on the Porte" (1913), commanded the troops that recovered Edirne, and later served as Minister of War. However, Albania became independent, Serbian territory was enlarged by 82 percent, Montenegro and Greece received similar gains, and Bulgaria was enlarged by about 30 percent.

Although many Turks, including those influential in the decisionmaking process, wanted to avoid participation in a new world conflagration immediately after three wars with tragic consequences, Enver Paşa and some other officers, who had their training in Germany, sought an alliance with that country, mainly stemming from their anxicty over Russian ambitions in the east and their understandable suspicion that Britain and France would not restrain Tsarist ambitions.

According to a secret alliance treaty (1914), Germany promised to champion Ottoman territorial integrity against Russia. The Turkish public was inflamed when Britain announced that the two newly-built battleships, which the Turks had paid for, were commandecred for use in His Majesty's navy. Germany conveniently offered Goeben and Breslau in their places, but the Ottoman Empire found itself at war with Russia and its allies when 
Admiral Wilhelm Souchon bombarded the Russian coasts in the Black Sea while his ship was flying the Turkish flag.

\section{The War Sets Out:}

I adhere to the view that the First World War was the result of imperialist competition between the great powers, principally between Britain and Germany on the one hand, and Germany and Russia on the other, each struggling for the division of the booty at the expense of smaller states and colonies.

Although this period of Iranian history is described in a fragmentary manner, ${ }^{14}$ it may be asserted that the country's leadership pursued a policy of neutrality, sometimes favourable to Germany and Turkey, and at times tilted towards Britain and Russia. When Germany moved to secure Iran's support for its war aims, Russia reacted by occupying the northern part of the country, the British holding the south. The war, which occasionally engulfed Iranian territory as well, was basically a Russo-Turkish hostility. Although the liquidation of the latter following the October Revolution should have lessened the burdens of Iran, the last year of the war was characterized by unilateral British military occupation.

Many members of the Ottoman Cabinet, the leaders of the party in power and the man in the strect knew that the country was not ready for another war, this time much more inclusive and hazardous. ${ }^{15}$ The Turks were

${ }^{14}$ P. Sykes, A History of Persia, London, 1930; W. E. D. Allen and P. Muratoff, Caucasian Battlefield, Cambridge, 1953; Emile Lesueur, Les Anglais en Perse, Paris, 1921; F. Kazemzadeh, The Struggle for Transcaucasia, New York, 1951; S. I. Siçov and V. K. Volkov, eds., Sovyetsko-Iranskiye Otnosheniya b dogovorah, konventsiyah i soglasheniyah, Moscow, Ministry of Foreign Affairs, 1946; H. G. Korsun, Pervaya Mirovaya Voyna na Kafkazskom Fronte, Moscow, 1946.

${ }^{15}$ Among the non-Turkish sources on the Ottoman entry into the war: E.R. Vere Hodge, Turkish Foreign Policy: 1914-1918, Geneva, 1950; F.G. Weber, Eagles on the Crescent: Germany, Austria and the Diplomacy of the Turkish Alliance: 1914-1918, Ithaca, New York, 1970; M. Larcher, La Guerre turque dans la guerre mondiale, Paris, 1926; H.N. Howard, The Partition of Turkey: A Diplomatic History: 1913-1923, Norman, Oklahoma, 1931; Liman von Sanders, Fünf Jahre Turkei, Berlin, 1920. Some leading Turkish sources: Fahri Belen, Birinci Cihan Harbinde Türk Harbi, 5 vols., Ankara, 196367; Ahmed Emin, Turkey in the World War, New Haven, Conn., and London, 1930; Arif Baytın, Ilk Dünya Harbinde Kafkas Cephesi, Istanbul, 1946; Djemal Pasha, Memoirs of a Turkish Statesman, London, 1921. 
hurled into it anyway, on account of Enver Paşa's behind-the-scenes maneuvres and the fait accompli of two German cruisers.

The Germans had initially considered Turkish support mainly against some Balkan states. But Turkey's potential opponent Bulgaria joined the Central Powers, and Serbia, with no choice but to join the Entente, was far away. Trying to keep Turkey away from the Balkans under the circumstances, Germany wanted to use, not only the Turks, but also the Iranians against Russia. Although it is true that the Ottoman Army, which had its own air force during the war, had been considerably modernized with German assistance, a small group of Ottoman decision-makers, led by Enver Paşa, had other war aims such as contemplating to recover some European territories including Thrace and Macedonia as well as north-castern Anatolia, Cyprus and Egypt.

\section{War On the Eeastern Front:}

I intend under this heading neither to offer a comprehensive outline of the armed hostilities in the eastern front of the First World War, nor avoid any mention of decisive developments elsewhere. I shall also hopefully try to confine whatever is mentioned, although very briefly, to its significance in Iranian-Turkish relations during the four years of the war.

One may start by underlining that both Iran and Turkey felt threatened by the presence of Russian troops on Iranian territory as well as in Transcaucasia. Before the war with the Turks, Russian forces consisted of nine infantry battalions, 2800 cavalry with 30 guns facing a Turkish gendarmeric division, frontier troops and Kurdish cavalry. The new Russian Caucasian army, under General Vorontsov-Dashkov, however, consisted of 150 battalions, 350 field guns and auxiliary companies against Hasan İzzet Paşa's 100 battalions and 244 guns. The threat was so real for so many interested parties that when the Iranian Government requested Russia to withdraw its troops from Azerbaijan, this plea was upheld, not only by the Turks, but also by the British.

It was the Russians who started the hostilities on 1 November 1914, and pushed across the border. The Armenians, including those who slipped away from the Turkish side to collaborate with Russian military officials, flooded into the Tsarist armies. Enver Paşa ${ }^{16}$ personally led the Third Army, based in Erzurum, in a successful counter-attack. But the subsequent Russian move caused the Turkish forces to scatter. The winter and fighting took away the lives of 70.000 Turkish soldiers in the ill-famed Sarıkamıs battle. After the Turkish defeat there and the news of the British landing at Gelibolu

${ }^{16}$ Şevket Süreyya Aydemir, Makedonya'dan Ortaasya'ya Enver Paşa, Vol. III, 1914-1922, Istanbul, Remzi, 1972. 
(Gallipoli), the Russian Government requested a preliminary determination of the postwar status of the Turkish Straits to be ascertained according to the centuries-old preferences of Russia.

The Allied effort to push through the Turkish Straits at the Dardanelles was beaten back, with 120.000 Ottoman casualties. Likewise, although the Russian offensives facilitated the position of the British forces in Mesopotamia, they could not save the 13.000 men at Kut el-Amara, who capitulated to the Turks, together with its commander Sir Charles Townshend (1861-1924). This was another significant British defeat after Gallipoli.

Although Halil Paşa, Enver's uncle, wanted to fortify the Turkish positions at Tigris to discourage the renewal of British attack, he was forced to enter into Iran to support German objectives there. As Halil Paşa correctly assumed, the British, under Sir Frederick Maude, captured Kut. By the time Halil Paşa could return from Iran, Turkish general Kâzım Karabckir had to evacuate Baghdad. Consequently, the British had taken the whole of Iraq except Mosul. The Russian troops in the north seized the port of Trebizond on the Black Sea coast, the fortress of Erzurum and penetrated into Erzincan.

Russian and British successes or defeats in their struggle against the Turco-German forces generally reflected in the foreign policy of the Iranian Government. Granted that the military operations of foreign troops, whether British, Russian or Turkish, were very unfavourable for a policy of neutrality, Iran itself was far removed from impartiality. Many members of the government and the Assembly expressed sympathies for Turkey and Germany. To the surprise of some interested parties, a circular of the government stated that anyone who would take arms against the Turkish Government would be severely punished. ${ }^{17}$

Hostility towards Russian and British occupation forces reached such heights that some politicians who assembled at Kum declared "holy war" on these two foreign states. Nizam el-Saltanat, the governor of Luristan, made an agreement with the Germans, who counted on Turkish military support. If the Germans and the Turks tried to use, at times unsuccessfully, the Bakhtiars, Lurs, Kashgairs, the Arabs of Khuzistan and some other tribes for anti-Russian and anti-British operations, this approach cannot be explained merely as propaganda or intrigue. ${ }^{18}$ Not only much depended on the preferences of the tribal chicfs, but also the people of Iran perccived the British and the Russians as intervening foreigners, whose actions trampled

${ }^{17}$ Unpublished dissertation on Iran's neutrality: T.S. Korotkove, " 'Neytralitet' Irana b Pervoy Mirovoy Voyne," Moscow, 1947, pp. 100-101.

${ }^{18}$ Oscar Niedermayer, Unter der gluttsonne Irans, München-Dachau, 1925. 
upon the sovereignty of the country. Neither the Mirza Kuchuk Khan episode of later date in Gilan was a coincidence, nor the German and Turkish supply of arms to his movement was without reason.

It is also natural, however, that the Iranians realized the potentials of Britain and Russia, especially as the fortunes of war changed. While the Provisional Government of Russia, following the February (March) 1917 Revolution, stuck to the positions of the previous Tsarist administration, the Bolsheviks, after the seizure of power in October (November) 1917, issued the "Appeal to All Muslims of Russia and the East", rejecting the Tsarist heritage in Iran.

When the Russian army started to withdraw, it was replaced by the British occupation forces, which received the inter-allied mandate to struggle, not only against the Turks, but also the Bolsheviks. A British force, under Major General L.C. Dunsterville, called "Dunsterforce", defeated Kuchuk Khan's troops with the help of the Cossack group, reaching Baku and staying there till mid-September 1918 when it hurried to Enzeli under the threat of the capture of the town by the Turks. ${ }^{19}$

But the operations in Iran or in the Caucasus had no decisive military importance. The main Turkish forces were concentrated in Syria and Palestine. Britain remained without rivals in Iran when Germany -and its allies- capitulated. But its political positions had been seriously undermined with the publication of secret agreements on the partition of both Iran and Turkey. Although Britain concluded, in mid-1919, with the Vossug-edDouleh's government an agreement, whose terms were close to a virtual protectorate over Iran, the tendency of the people in favour of liberation could not be crushed, and Britain felt compelled to withdraw in 1921.

\section{The Armenian Question:}

The "Armenian question" has some place in Turkey's relations with Russia and the Caucasian peoples, especially during the war years. This paper will not attempt to define it in historical perspective or to treat the issue within the limits of the years under discussion. ${ }^{20}$ One may be content to emphasize that, in spitc of a host of publications covering various vicws, especially those emanating from Armenian circles, considerable balanced studies are still needed to determine the degree of responsibility that falls on each of the partics involved in the displacement of Armenians, which may well be the core issue in the general debate. I must underline once more,

${ }^{19}$ L.C. Dunsterville, The Adventures of Dunsterville, London, 1920; M.H. Donohoe, With the Persian Expedition, London, 1919.

${ }^{20} \mathrm{I}$ have more-or-less done that in the 76 books and booklets that I published since the early 1980 s. 
however, that this paper does not consider the Armenian question per se within the frame of reference of this international round table. Some citations may be expected, nevertheless, as much as they bear on the development of the war.

As war clouds increasingly gathered in the oppressive horizon of world politics, the Armenians and Turks pondered on what their relations would be in the future. The Turks came to the Armenian congress in Erzurum (1914) and offered an autonomous Armenia if they would not withhold their support in the expected war. It was decided during that congress that in the event of a Russo-Ottoman hostility, the Armenians in Turkey would not oppose their government.

But authorized Armenians, above all, inform us that this decision was not followed. Tu cut a long story short, as K. S. Papazian noted, "the leaders of the Turkish-Armenian section of the Dashnagtzoutune did not carry out their promise of loyalty" to the Turks but instead "were swayed in their actions by the interests of the Russian Government." 21 Similarly, Hovhannes Katchaznouni, the first prime minister of the independent Armenian Republic, wrote as follows in an important book, originally "a manifesto" he had presented to the convention of foreign branches of the Armenian Revolutionary Federation (Bucharest, 1923):

Contrary to the decisions taken during the general meeting at Erzurum only a few weeks before, the A.R.F. had (actively participated) in the formation of the bands and their future military action against Turkey... We had lost our sense of reality and were carried away with our dreams... We ought to have used peaceful language with the Turks... When the skirmishes had started the Turks proposed that we meet and confer. We did not do so and defied them...22

When the Ottoman Government decreed mobilization, VorontsovDachkov, the Russian general of Caucasia, wrote (1914) to the Armenian Catholicos of Etchmiadzin: "...Use your authority over your congregation, and ensure that our Armenians and those who reside in the border regions implement the duties and services which I shall ask them to carry out in the

${ }^{21}$ K.S. Papazian, Patriotism Perverted, Boston, Baikar Press, 1934, pp. 37-38; Türkkaya Ataöv, An Armenian Author on "Patriotism Perverted", Ankara, Sistem Ofset, 1984.

${ }^{22}$ Hovhannes Katchaznouni, The Armenian Revolutionary Federation (Dashnagzoutiun) Has Nothing to Do Any More, New York, Armenian Information Service, 1955, pp. 5, 9-10; Türkkaya Ataöv, A n Armenian Source: Hovhannes Katchaznouni, Ankara, Sistem Ofset, 1984, pp. 4, 8. 
future, in the event of a Russo-Turkish war..."23 Several Armenian authors, A. P. Hacobian for instance ${ }^{24}$, or G. Pasdermadjian, ${ }^{25}$ who was one of their commanders, and a number of others ${ }^{26}$ admit that the Russian Caucasian army was largely composed of Russian Armenians. Having rendered great service to Russia, the Tsar visited the Armenian Cathedral in Tbilisi demonstrating his satisfaction with the part played by Armenians in the war.

When the Russian forces started the hostilities, Armenian leaders in Russia declared open support to them. It is important to note that before the Ottoman relocation orders Dashnaks from Russian Armenia led the revolt in the Ottoman province of Van, and within a matter of a month an "Armenian state" was set up there under Russian protection. ${ }^{27}$

After the Bolsheviks disclosed the secret agreements partitioning the Ottoman Empire, and declared the treaty that carved out an Armenia out of eastern Anatolia as null and void, the Ottoman representatives at the Brest Litovsk Conference tried to regain the lost provinces. Russia agreed to evacuate the eastern provinces, Iran and the Caucasus. But the Armenian units continued their hostility towards the remaining Turkish cultivators in the east. ${ }^{28}$ It was Karabckir's army that advanced as the Russians retreated. While the Armenians, who hoped to settle in eastern Anatolia, had to follow the Russian troops back to the Caucasus, the Ottoman armics seemed to confront, this time, the German allies who were also interested in the same area, principally on account of Azeri oil. Also influenced by Armenian appeals, the Germans reached an agreement with Russia (1918) to keep the Turks away from the Caucasus as much as possible.

${ }^{23}$ Kamuran Gürün, The Armenian File, London, etc., K. Rustem and Bro. and Weidenfeld and Nicolson Ltd., 1985, p. 190.

${ }^{24}$ A.P. Hacobian, Armenia and the War, London, New York, Toronto, Hodder and Stoughton, 1917.

${ }^{25}$ G. Pasdermadjian, Why Armenia Should Be Free: Armenia's Role in the Present War, Boston, Hairenik Publishing Company, 1918.

${ }^{26} \mathrm{G}$. Korganoff, La Participation des Arméniens à la guerre mondiale sur le front du Caucase: 1914-18, Paris, Imp. Massio, 1927; Also see series of articles by Gabriel Gorganian in The Armenian Review, beginning with the Summer 1968 issue.

${ }^{27}$ Stanford J. Shaw, and Ezel Kural Shaw, History of the Ottoman Empire and Modern Turkey, Vol. II, Cambridge, Cambridge University Press, 1978, pp. 314-317, 322-323.

28 A. Poidebard, Le Role militaire des Arméniens sur le front du Caucase après la défection de l'armée russe (Déc. 1917-Nov. 1918), Paris, Imp. Nationale, 1920. 


\section{Conclusion:}

Since the history of the First World War as it affected Iran has not been investigated sufficiently in the past, this initiative of the "Institut Française de Recherche en Iran" (IFRI) is most appropriate. Evidence suggests that Iran pursued a policy of neutrality during the war, favourable at times to one or the other side depending on the circumstances beyond its will. It may also be claimed that Iranian policy towards Turkey has been generally friendly. Although one of the characteristic attributes of the Iranian people is dislike of repeated foreign interventions, occasional Turkish presence on Iran's territory was partly tolerated as a calculated counter-weight, albeit uneven, to long and depressive Russian and British occupations. Iranian diplomacy was based, for centurics, on balancing various powers and acquiring some freedom of action in the process. But by 1914 very little had remained of the sovereignty of Iran.

Germany apparently wished to have access to the shores of the Persian Gulf. It may also be added that Turkey as well tried to extend its borders eastwards, initially to regain lost territories. But a number of Western publications, particularly British ones, greatly exaggerate the dimensions of German -and Turkish- expansions in or around Iran during the war years, probably to justify Britain's own prevalence there, accompanicd by aggressive actions. It is no surprise that, by the end of the war, Iranian territory was occupicd by British troops.

The distribution of power was so much altered after the Bolshevik Revolution and the end of the war that the representatives of the Ankara government were the largest foreign delegation in the first Congress of the Peoples of the East, held in Baku (1920), and the Iranians were the second group. This was a response for the quest of the victors for vengeance. The 1920 s which brought nationalist and reformist governments to power in Iran and Turkey witnessed the setting aside of various former opposition between the two. The settlement of the border issues, however, had to await the year 1932. 